A RT. VI.-Contributions from the Sheffield Laboratory of Yale College. No. XXXIV.-On Zonochlorite and Chlorastrolite; by GEORGE W. HAWES.

At the meeting of the American Association for the Advancement of Science which was held at Dubuque, Iowa, in 1872, Prof. A. E. Foote described "a new hydrous silicate" found at Neepigon Bay, on the north shore of Lake Superior. $†$ It is a hard, green mineral occurring in the amygdaloidal trap, associated with calcite, quartz, and various zeolites: and it is also found in the form of smooth water-worn pebbles upon the shore. This mineral, on account of its structure, he called $Z$ ono. chlorite, since many of the specirnens are beautifully banded; and his analysis convinced him that it was a zeolite. The stones which he regarded as pure were of a uniform dark green color; while

* Bericht Deut. Chem. Ges., 26th Ap., 1875.

+ Proceedings of the American Association for the Advancement of Science, 21 st meeting, August, 1872, p. 65. 
those which were very plainly banded with white he considered impure. But thin sections of some of the dark green stones, received from Prof. Foote, and considered by him as the purest zonochlorite, when examined under the microscope, show that these, like the other specimens, are more or less banded and consist of green earthy particles disseminated through a white mineral. A dark green specimen gave me, on analysis, the following composition :

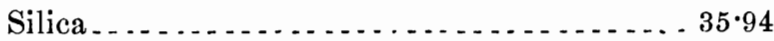

Alumina . . .

Ferric oxide $\ldots \ldots \ldots \ldots$

Ferrous oxide $\ldots \ldots \ldots \ldots \ldots \ldots \ldots$

Lime ...

Magnesia $\ldots \ldots \ldots \ldots \ldots \ldots \ldots$

Soda . . . . . . . . . . . .

Water............................ $8 \cdot 40$

$100 \cdot 34$

The analysis indicates that the mineral is a very impure variety of prehnite, a mineral which is common in the trap of that region; and its bardness and behavior before the blow. pipe point to the same conclusion. The analytical results obtained by Prof. Foote show that the material he examined was not boinogeneous, as he states that the percentage of water, the average of which was $8 \cdot 7$, varied from 7.03 to $12 \cdot 9$. The presence of magnesia shows that a portion of the impurity is chlorite.

Zonocblorite in its mode of occurrence resembles Chlorastrolite, ${ }^{*}$ which is found on the shores of Isle Royale in rounded pebbles derived from the amygdaloidal trap, and has also been found in place in the trap. At the suggestion of Prof. Brush, who placed at my disposal the specimens which were brought by him from Lake Superior, thin sections were made from some of the best stones in his possession: and the microscopic examination of these made it very evident that chlorastrolite is not a homogeneous substance-the impurities in this case being distributed through a white mineral of a radiated structure; and to the irregular arrangement of the pure and impure material the stone owes its beauty. When a flat surface is cut upon one of these stones, the polished face presents various shades of green; but when the other side is cut away, thus making a thin section of the stone, those spots which have the deepest green are found to be perfectly clear and white, receiving their deep green shade from the colored surfaces beneath. The green

* Boston Journal of Natural History, vol. v, p. 488. Report on the Geology of the Lake Superior Land District, Part II, p. 97. Dana's Mineralogy, 5th edition, p. 412. 
impurities are arranged along lines radiating from these clear centers, till at some distance the mixture becomes so intimate as to appear nearly homogeneous until more highly magnified. An analysis of a very fine stone gave the following result:

I.

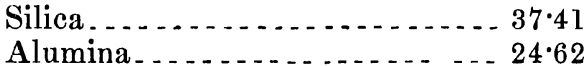

Ferric oxide ................ 2.21

Ferrous oxide .............. $1 \cdot 81$

Lime . . . . . . . . . . . . . . . . . 2 22 20

Magnesia ................... $3 \cdot 46$

Soda . . . . . . . . . . . . . . . . . 34

Water ..................... $7 \cdot 72$
II.

$\cdot 30$

\section{$99 \cdot 77$}

The essential difference between this analysis and those by Prof. J. D. Whitney is, that the percentages of magnesia and soda have exchanged places, since he obtained no magnesia and 4 per cent. of soda. For this reason, I repeated my alkali determination upon another sample prepared from portions of several stones, but with no variation in the result, as will be seen in No. II above. This great difference can be accounted for in no way save by the evidence, which the microscopic examination affords, that the stones are mixtures of minerals which have been carried into the amygdaloidal cavities of the trap. The stones that I have seen appear to consist, like the zonochlorite, largely of impure prehnite. The higher specific gravity may be due to an enclosure of epidote, which is everywhere associated with the chlorastrolite in the rocks, and moreover is often present in the same cavity. 